\title{
Depression in the student medicine: a literature review
}

\author{
Depressão no estudante de medicina: uma revisão de literatura \\ Depresión en estudiantes de medicina: revisión de la literatura
}

Received: 09/06/2021 | Reviewed: 09/12/2021 | Accept: 09/17/2021| Published: 09/18/2021

Tauanne Fernanda dos Santos

ORCID: https://orcid.org/0000-0002-7075-8031 Universidade Anhanguera -UNIDERP, Brazil E-mail: tauannef@icloud.com

Gleyson Murillo Aguilera Moraes

ORCID https://orcid.org/0000-0002-9134-2609 Universidade Anhanguera -UNIDERP, Brazil

E-mail: murillomoraes_@hotmail.com

Mellânia Rodrigues Goveia

ORCID https://orcid.org/0000-0003-0937-7472

Universidade Anhanguera -UNIDERP, Brazil

E-mail: goveiamellania@gmail.com

Marco Antônio de Souza Borges Tavares

ORCID https://orcid.org/0000-0002-9552-6990

Universidade Federal de Mato Grosso do Sul, Brazil

E-mail: mantoniosouzza@gmail.com

Jouse Maiane Gonçalves Torres

ORCID https://orcid.org/0000-0002-0356-2995 Universidade Estadual de Mato Grosso do Sul, Brazil

E-mail: jousemaiane123@gmail.com

Josimar José Torres

ORCID https://orcid.org/0000-0001-5646-5825

Universidade Estadual de Pernambuco, Brazil

E-mail: josimartorresmed95@gmail.com

Lanúbia Garcia de Araújo Vasconcelos

ORCID https://orcid.org/0000-0003-0320-0510

Universidade Anhanguera -UNIDERP, Brazil

E-mail: lanubiagarcia@hotmail.com

Damerson Muriel Souza Vasconcelos

ORCID https://orcid.org/0000-0001-8970-6795

Universidade Federal de Mato Grosso do Sul, Brazil E-mail: damersonmuriel@live.com

Maria Borges Tavares

ORCID https://orcid.org/0000-0001-8324-1536

Universidade Anhanguera -UNIDERP, Brazil

E-mail: maria_tavaresh4@hotmail.com

\begin{abstract}
Associated with functional impairment and impaired physical and mental health, depression is characterized as a multifactorial mood disorder. In the clinic there is sadness, pessimism, low self-esteem, lack of pleasure, mood swings and suicidal thoughts and acts. Therefore, this narrative review aims to understand depression in the medical-student environment and associated factors. It was researched: "depression"; "Depression in medical students"; "Depression among medical students" in Bireme, PubMed and Scielo. A total of 431 articles were found, from 2012 to 2019, and 14 responded to: "how did depression manifest itself among medical students?". Studies show a high risk for physicians and medical students to develop mental exhaustion, depressive symptoms, alcohol abuse, and a tendency to commit suicide. As for students, medical schools require a strenuous routine, with little leisure. Added to this is the pressure from parents and teachers and the fear of failure. At least $25 \%$ of medical students have some kind of psychological distress originated in academic training. Mayer found depressive symptoms in $41 \%$ of students; $81.7 \%$ presented state anxiety and $85.6 \%$, trait anxiety. Souza noted a predominance of depression in medical students than in the general population. Faced with this susceptibility, teachers must be able to recognize depressive signs and symptoms in students so that there is an early and effective intervention.
\end{abstract}

Keywords: Depression; Depression in the student environment; Evil of the century; Depression in the medical environment. 


\begin{abstract}
Resumo
Associada à deficiência funcional e à saúde física e mental prejudicada, a depressão é caracterizada como um transtorno do humor multifatorial. Na clínica há tristeza, pessimismo, baixa autoestima, falta de prazer, oscilações de humor e pensamentos e atos suicidas. Portanto, esta revisão narrativa objetiva compreender a depressão no ambiente médico-estudantil e fatores associados. Pesquisou-se: "depressão"; "Depressão em estudantes de medicina"; "Depressão no meio do estudante de medicina" em Bireme, PubMed e Scielo. Foram encontrados 431 artigos, do período de 2012 a 2019, e 14 responderam a: "como a depressão se manifestou entre os estudantes de medicina?". Estudos mostram um alto risco de médicos e estudantes de medicina desenvolverem exaustão mental, sintomas depressivos, abuso de álcool e tendência ao suicídio. Quanto aos alunos, as escolas médicas exigem uma rotina extenuante, com pouco lazer. Soma-se a isso a pressão de pais e professores e o medo do fracasso. Pelo menos $25 \%$ dos estudantes de medicina apresentam algum tipo de sofrimento psíquico originado na formação acadêmica. Mayer encontrou sintomas depressivos em $41 \%$ dos alunos; $81,7 \%$ apresentaram ansiedade-estado e $85,6 \%$, ansiedade-traço. Souza observou um predomínio de depressão em estudantes de medicina do que na população em geral. Diante desta suscetibilidade os professores devem ser capazes de reconhecer sinais e sintomas depressivos nos alunos para que haja uma intervenção precoce e eficaz.
\end{abstract}

Palavras-chave: Depressão; Depressão no ambiente estudantil; Mal do século; Depressão no ambiente médico.

\title{
Resumen
}

Asociada con deterioro funcional y deterioro de la salud física y mental, la depresión se caracteriza como un trastorno del estado de ánimo multifactorial. En la clínica hay tristeza, pesimismo, baja autoestima, falta de placer, cambios de humor y pensamientos y actos suicidas. Por lo tanto, esta revisión narrativa tiene como objetivo comprender la depresión en el entorno del estudiante de medicina y los factores asociados. Se investigó: "depresión”; "Depresión en estudiantes de medicina"; "Depresión entre estudiantes de medicina" en Bireme, PubMed y Scielo. Se encontraron un total de 431 artículos, de 2012 a 2019, y 14 respondieron a: “¿cómo se manifestó la depresión entre los estudiantes de medicina?". Los estudios muestran un alto riesgo para los médicos y estudiantes de medicina de desarrollar agotamiento mental, síntomas depresivos, abuso de alcohol y tendencia al suicidio. En cuanto a los estudiantes, las facultades de medicina requieren una rutina extenuante, con poco tiempo libre. A esto se suma la presión de los padres y maestros y el miedo al fracaso. Al menos el $25 \%$ de los estudiantes de medicina tienen algún tipo de malestar psicológico originado en la formación académica. Mayer encontró síntomas depresivos en $41 \%$ de los estudiantes; El $81,7 \%$ presentó ansiedad estado y el 85,6\% ansiedad rasgo. Souza notó un predominio de la depresión en los estudiantes de medicina que en la población general. Ante esta susceptibilidad, los profesores deben ser capaces de reconocer los signos y síntomas depresivos en los alumnos para que exista una intervención temprana y eficaz.

Palabras clave: Depresión; Depresión en el entorno estudiantil; Maldad del siglo; Depresión en el ámbito médico.

\section{Introduction}

Depression is a medical pathology of high incidence, being considered a serious public health problem worldwide, affecting approximately 350 million people and may culminate in disability-adjusted life years, with chronic and recurrent manifestations (Nóbrega, et al., 2020). It is commonly associated with functional impairment and impairment of the patient's physical and mental health. It is characterized as a multifactorial mood disorder that involves affective, motivational, cognitive and neurovegetative aspects that must be considered and analyzed together to obtain an adequate assessment and treatment (Hepgul, et al., 2013).

The disease is considered by the World Health Organization (WHO) as the "Evil of the Century", given its high prevalence and the involvement of different classes, genders and ages. Regarding the clinical picture, there is the presence of sadness, pessimism, low self-esteem, which manifest themselves frequently and can be combined. In addition, there is a lack of pleasure in things that were once good for the affected patient, an extensive swing of mood and thoughts, which can culminate in suicidal behavior and acts. In addition, depression also induces physiological changes in the body, being a gateway to other diseases. Patients affected by depression have a low immune system and more episodes of inflammatory and infectious pathologies (Brasil, 2018).

Given the importance of the topic, its unresolvable approach within universities and the resulting consequences, this review aims to understand depression in the student's medical environment and the factors associated with such a situation, in order to promote reflections and debates on the subject. 


\section{Methodology}

The work presented here is a qualitative research of the narrative review type (Koche, 2011), whose methodology was a bibliographic research based on literature already published in the following databases: Bireme, PubMed and Scielo; having been accepted as bases of choice, given their importance in the academic medical field. The articles were obtained using the following descriptors: "depression"; "depression in medical students"; "Depression among medical students". In this sense, a total of 431 articles were found, however, every article needs one or several revisions in relation to the wording, content and bibliographic references (Pereira, et al., 2018), among which we selected only those that included among the years from 2013 to 2021 , to review the latest on the topic; as well as the articles that answered the following guiding question: "how has depression manifested among medical students?". Subsequently, a total of 21 articles were obtained, all discussed here.

\section{Results and Discussion}

Studies show a high risk of physicians and medical students developing mental exhaustion, depressive symptoms, marital problems, alcohol abuse, among other types of drugs, and greater propensity to commit suicide. It is also known that these two social groups are more likely to develop mental pathologies compared to the rest of society; The aggravating factor of the situation is the fact that these segments hardly seek professional help, a situation that accentuates the situation and makes treatment difficult (Karaoglu \& Seker, 2010; Tabalipa, et al., 2015). Common mental disorders involve psychological distress and interfere with daily activities, interpersonal relationships and quality of life. It is estimated that they reach $9 \%$ to $12 \%$ of the world population and $12 \%$ to $15 \%$ of the Brazilian population in all age groups. Among the different social groups, physicians in training are more vulnerable to developing anxiety and depression disorders (Sacramento, et al., 2021).

With regard to students, it appears that medical schools are recognized as places of education that are extremely judicious in their activities, a fact that demands from the academic a strenuous study routine and little or no leisure. Such a situation can have a negative impact on the student's academic performance, as well as on their overall health. Added to this is the academic's great difficulty in adapting to the new environment, as many leave their cities, where they have emotional ties, and start to live without the physical support of their parents (Gramstad, Gjestad \& Haver, 2013; Tabalipa, et al., 2015).

In addition, students have a number of extra concerns, such as: pressure exerted by parents and teachers in relation to academic performance, which is commonly manifested by the fear of failure (Galvão, et al., 2021), as well as the concern with availability of vacancies in medical residencies and in the labor market. Such factors, when associated with the increasing manifestation of the most diverse emotional outbursts, negatively influence their study routine, in addition to affecting physiological and cognitive functions, compromising learning, quality of life and patient care (Oliveira \& Araujo, 2019). It is known that at least $25 \%$ of medical students have some kind of psychological distress and that it originated in academic training, with anxiety and depression being the most prominent disorders (Gramstad, Gjestad \& Haver, 2013; Tabalipa, et al., 2015).

Depression and stress were detected more frequently among Brazilian medical students than among American students (Lucchetti, et al., 2018). It is estimated that $15 \%$ to $25 \%$ of Brazilian university students present some type of psychiatric disorder during their academic training. Among these disorders, depressive and anxiety disorders are the most frequent (Vasconcelos, et al., 2014).

The climate of tension and distressing feelings can worsen during the medical course, as several factors, such as pressure to learn a lot of new information, little time for leisure activities, contact with death and serious illnesses at an early age (Figueiredo, et al., 2014; Peres, et al., 2014), contribute to the deficit in mental health and worsening of quality of life (Peres, et al., 2014). 
In the doctoral study, Mayer, et al., (2016) analyzed the frequency and factors that point to symptoms of depression and anxiety among medical students. The researcher measured anxiety symptoms in two ways: state anxiety, that is, the anxious state, something momentary; and trait anxiety, a personality trait, in which the person tends to react more anxiously to adverse situations. Depressive symptoms were attested in $41 \%$ of students; $81.7 \%$ presented state anxiety and $85.6 \%$, trait anxiety. All three symptoms were positively associated with female students and students from medical schools located in capitals of both genders. Scholarship students had higher state anxiety, but not trait anxiety or depression scores.

In the meta-analysis by Rotenstein, et al., (2016), the global prevalence of depression or depressive symptoms among medical students was $27.2 \%$ and the global prevalence of suicidal ideation was $11.1 \%$. Among medical students testing positive for depression, $15.7 \%$ sought psychiatric treatment.

In addition, currently, the analysis of Sartorão (2021) demonstrated a significantly higher prevalence of moderate and severe anxiety and depression symptoms among female medical students during the COVID-19 Pandemic.

Regarding the conclusion of the research analyzed by Souza, et al., (2017), it was observed that there is a higher prevalence of depression in medical students than in the general population, which can be understood by the experience and proximity of this population with the death, illness and crisis situations, as well as the involvement of students with responsibility towards life. The studies also showed that the medical student is subject to a greater and significant vulnerability due to factors and characteristics of the course, warning about the compromise of their quality of life and health (Santa \& Cantilino, 2016).

These numbers are justified because, during graduation, students may suffer losses in the psychological domain, which will bring important implications for the health of future physicians. According to Buhrer, et al., (2019), high emotional strain causes inadequate adaptation to difficulties, leading to indifference and insensitivity attitudes. This routine feeling leads to a feeling of failure and the activities become meaningless (Costa, et al., 2012). Therefore, it is believed that higher education institutions must commit to the integral development of their students by presenting institutional strategies to face this reality (Costa, et al., 2020).

\section{Conclusion}

In view of the data presented here, we can see the susceptibility of medical students to depression. As it is a pathology in which, commonly, there are no organic symptoms, the disease often ends up being neglected, so the student is placed in a chronic situation of suffering. Fact that hinders their development both in the student and family environment. Thus, the approach by the faculty about the manifestation of the theme in its students is of paramount importance. Ideally, teachers should be able to recognize depressive signs and symptoms among their students so that there is an early and effective intervention.

Given the above, the possibility of multiprofessional research is highlighted to quantify the level and form of interventions needed to alleviate the already established repercussions of depressive symptoms in the medical-student environment and enable forms of prevention that can be applied in the population in question in order to avoid further damage in the future.

\section{References}

Brazil. (2018) Ministry of Health. Health Department (Org.). Depression: causes, symptoms, treatments, diagnosis and prevention. of Paraná. Rev. bras. education med., Brasilia, 43(1), 39-46. 10.1590/1981-52712015v43n1RB20170143 
Costa D. S., Medeiros N. S. B., Cordeiro R. A., Frutuoso E. S., Lopes J. M., \& Moreira S. N. T. (2020). Symptoms of Depression, Anxiety and Stress in Medical Students and Institutional Coping Strategies. 10.1590/1981-5271v44.1-20190069

Costa, E. F. O., Santos, S. A., Santos, A. T. R. A., Melo, E. V., \& Andrade, T. M. (2012). Burnout Syndrome and associated factors among medical students: a cross-sectional study. Clin; 67 (6) 573 - 579. 10.6061/clinics/2012(06)05

Figueiredo, A. M., Ribeiro, G. M., Reggiani, A. L. M., Pinheiro, B. A., Leopoldo, G. O., Duarte, J. A. H., Oliveira, L. B., \& Avelar L. M. (2014). Perceptions of ufop medical studentes about their quality of life. Rev. Bras. Education av.; 38 (4) 435 - 443. 10.1590/S0100-55022014000400004

Galvão, A. P. F. C., Duailibe, I. M. L., Aragão, F. B. A., Santos, N. M., Carvalho, E. R. O., \& Uchida, R. R. (2021). Anxiety: Predisposing factors in college students for mental illness. Brazilian Journal of Development. 7(5). 10.34117/bjdv7n5-439

Gramstad, T. O., Gjestad, R., \& Haver, B. (2013). Personality traits predict job stress, depression and anxiety among junior physicians. BMC Med.; 13:150.

Hepgul, N., Cattaneo, A., Zunszain, P. A., \& Pariante, C. M. (2013). Depression pathogenesis and treatment: what can we learn from blood mRNA expression?. BMC Medicine.

Karaoglu, N., \& Seker, M. (2010). Anxiety and depression in medical students related to desire for and expectations from a medical career. West Indian med., Mona, 59(2), mar. PMID: 21275126

Lucchetti, G., Damiano, R. F., DiLalla, L. F., Lucchetti, A. L. G., Moutinho, I. L. D., Ezequiel, O. S., \& Dorsey, J. K. (2018). Cross-cultural differences in mental health, quality of life, empathy, and burnout between US and Brazilian medical students. Acad Psychiatry. 10.1007/s40596-017-0777-2

Mayer, F. B., Santos, I. S., Silveira, P. S. P., Lopes, M. H. I., Souza, A. R. N. D., Campos, E. P., Abreu, B. A. L., Hoffman Li I., Magalhães, C. R., Lima, M. C. P., Almeida, R., Spinardi, M., \& Tempski, P. (2016). Factors associated with depression and anxiety in medical students: a multicenter study. 10.1186/s12909-016-0791-1

Nóbrega, W. F. S., Oliveira, M. E. C., Gomes, K. A. L., Palmeira, J. T., Barbosa, D. V., \& Silva, G. C. B. (2020). Depression in academic life: wich factors are associated?. Research, Society and Development, 9, (8). 10.33448/rsd-v9i8.5719

Oliveira, M. F., \& Araujo, L. M. B. (2019). Mental Health of the medicine student. Brazilian Journal of Development. 10.34117/bjdv5n11-058

Pereira, A. S., Shitsuka, D. M., Parreira, F. J., \& Shitsuka R. (2018). Metodologia da pesquisa científica. Santa Maria/RS. Ed. UAB/NTE/UFSM.

Peres, M. F. T., Barreto, A. D. L., Babler, F., Quaresma, I. Y. V., Arakaki, J. N. L., \& Eluf-Neto, J. (2014). Exposure to violence, quality of life, depression, and burnout among medical students in a state university of São Paulo. RevMed. 1 0.11606/issn.1679-9836.v93i3p115-124

Rotenstein, L. S., Ramos, M. A., Phil, M., \& Torre, M. (2016). Prevalence of Depression, Depressive Symptoms, and Suicidal Ideation Among Medical Students: A Systematic Review and Meta-Analysis. 10.1001/jama.2016.17324

Sacramento, B. O., Anjos, T. L., Barbosa, A. G. L., Tavares, C. F., \& Dias J. P. (2021). Sintomas de ansiedade e depressão entre estudantes de medicina: estudo de prevalência e fatores associados. 10.1590/1981-5271v45.1-20200394

Santa, N. D., \& Cantilino, A. (2016). A Review of Literature on Suicide among Doctors and Medical Students. Revista Brasileira de Educação Médica. 10.1590/1981-52712015v40n4e00262015.

Sartorão Filho, C. I., Rodrigues, W. C. de L. V., Castro, R. B., Marçal, A. A., Pavelqueires, S., Takano, L., Oliveira, W. L., \& Sartorão Neto, C. I. (2021). Moderate and severe symptoms of anxiety and depression are increased among female medical students during the COVID-19 pandemic. Research, Society and Development, [S. 1.], 10(6), e34610615406. 10.33448/rsd-v10i6.15406.

Souza, A. S., Tavares, K. M., \& Pinto, P. S. P. (2017). Depression in medical students: a systematic literature review.

Tabalipa, F. O., Souza, M. F., Pfützenreuter, G., Lima, V. C., Traebert, E., \& Traebert, J. (2015). Prevalence of Anxiety and Depression among Medical Students. Rev.br. education med, Rio de Janeiro, 39(3), jul. 10.1590/1981-52712015v39n3e02662014

Vasconcelos, T. C., Dias, B. R. T., Andrade, L. R., Melo, G. F., Barbosa, L., \& Souza, E. (2014). Prevalence of Anxiety and Depression Symptoms in Medical Students. 2014. Revista Brasileira de Educação Médica. 